\title{
Most common accidents and best safety strategies to reduce accidents in Northern Iraq construction projects
}

\author{
Shivan Jalal Ali \\ Faculty of Civil and Environmental Engineering, Near East University, Nicosia, Mersin 10, Turkey
}

ARTICLE INFO

ARTICLE HISTORY:

Received: 29 April 2020

Revised: 14 May 2020

Accepted: 14 May 2020

Published: 19 June 2020

\section{KEYWORDS:}

Most common accidents, safety, construction, falling from heights

\begin{abstract}
A B S T R A C T
Worldwide, the construction sector is one of the riskiest sectors. Although reducing accidents is not easy, but it is possible at the same time. To design solutions to prevent accidents, it is essential to know the most common accidents and also to get the opinion of people with experience. Knowing these things will allow effective strategies to be designed based on the causes and the common accidents compared to the current safety system will result in an effective safety method to be undertaken. This paper identifies the most common accidents in Northern Iraq construction projects and identifies and examines practical ways to reduce accidents that ensure good safety performance. The study has been conducted by applying a questionnaire to collect data from stockholders about how effective ways have shown promising results in reducing accidents. On this basis, it suggests the best strategies to be undertaken. The results of the current study illustrated that the most common accidents in construction projects are falling from heights, struck-by accidents in highway construction and also found effective ways to reduce accidents in construction projects in general and highway projects as well.
\end{abstract}

\section{INTRODUCTION}

The construction sector is one of the riskiest industries, where many workers are being killed every day or injured. There are many types of accidents that cause death and injury to the staff. In today's world, the issue of a safety system is needed (Fung et al., 2005). However, to design an effective safety strategy, there is a need to know the most common accidents in that place. Knowing this thing can give an idea of the accidents types so safety systems will be designed according to them.

Safety management is supposed to consider all hazards that might reasonably be expected to place workers of the project at danger. It is, therefore, essential to define acceptable safety practices and policy and address possible serious concerns (Zhao et al., 2018).

Safety management is the method used to identify safety risks and to introduce measures to minimize the potential for risk and to decrease the possible effects of established safety hazards from the project (Ferrett \& Hughes, 2015).

Previous work in the field indicates that construction projects pose numerous potential risks to workers' lives, and bad injuries and deaths are common in the construction sector. Some of the various safety hazards in construction can be avoided by careful safety preparation (Irimie et al., 2015).

The improvement of safety in construction is, therefore, still an essential task for all stakeholders to the construction operations. In order to reduce these hazards, safety management is inclined to consider all threats and incidents that are likely to be found to place project workers at risk (Reese, 2018).

Northern Iraq is a developing region where many construction projects are being done every day, wherein in 2019, 38 workers were killed (Alsumaria, 2019). So, it is crucial to know and improve the safety system in the region.

There are several forms of incidents in the construction industry, and they can be caused by a vehicle, falling from a height, equipment accidents etc.

Generally, the type of accidents also depends on the kind of worksite, wherein building and high rising constructions the falling from heights is usually common but in highways construction struck-by vehicles.

Because of their seriousness and frequency, slipping, and falling accidents in the building have gained serious notice and were highly researched (Australia, 2013). 
Compared to the level of accidents, falls from height have the highest levels of construction fatalities relative to other forms of accidents (Hanapi et al., 2013). Meanwhile, in the UK building industry between 1997-2003, electric injuries were $7 \%$ and being hit by vehicles were $14 \%$, items shifting $17 \%$, 9\% collapsing and $46 \%$ falling from heights (Howarth, \& Watson, 2009).

Struck-by accidents are very popular in road construction as the work areas are danger zones as well as there are always large moving vehicles used during the construction (Pigman, 1988).

Among the other variables cited as causes for the rise in fatality rates are an improper use of traffic control equipment, poor traffic management, and insufficient layout of the overall work area (Persia et al., 2016).

During the peak season, almost $20 \%$ of the U.S. highway system is under construction, which involves over 3000 construction sites. On average, three people lose their lives each day in road building accidents annually, more than 40,000 people get injured as a result of work zone collisions (OSHA, 2020).

Falling from heights is a significant public risk and among the main causes of severe fatal injury to workers, where $49 \%$ of fatalities in a five-year span, according to Construction Statistics in Britain, were due to falling from heights (HSE, 2019).

The construction workers constitute a high-risk community for falling from heights (Janicak, 1998). Also, the number of fatal incidents in various sub-sectors has risen due to falls at the construction sites (Derr et al., 2001). Moreover, the majority of injuries in the United States are falling from heights (Huang \& Hinze, 2003; Schaufelberger $\&$ Lin, 2013). In Spain, falling from height accidents in the construction sector consisted of $50 \%$ of all work accidents (Romero et al., 2013). They noted that around 40 per cent of accidents happen as a result of falling from heights. Besides, about $30 \%$ of these falls from momentary devices on structures assembled at height to labour (i.e. scaffolding).

According to Griffith and Howarth (2001), the fundamental causes of accidents through scaffolding installation and demolition are due to platforms lacking safety from the edges. Furthermore, additional scaffolding studies are needed to reduce and monitor the number of incidents due to being unsafe (Romero et al., 2013). The falling materials and artefacts were the second most prevalent risk of fatalities (Griffith \& Howarth, 2001).

Falls are the primary cause of severe injuries (48\%) and fatalities (30\%) of all accidents (Hu et al., 2011). Falling from heights accounts for more than $35 \%$ of accidents, and is the leading cause of bad injuries and deaths (BLS, 2015). In 2013, falling from heights accounted for $36.9 \%$ of the U.S., $31 \%$ in the UK, and $12 \%$ in Australia workplace deaths (HSE, 2015).

Past review papers concentrated on specific strategies, such as factors that affect behaviours, scaffolds/platforms or methods for avoidance of dropping, and behavioural field studies for workers (Hu et al., 2011). Building deaths and severe fall-induced injuries have attracted attention from several researchers. Analysis of factors that generally influence fall risks (Hu et al., 2011). Also, Jebelli et al. (2014) carried out research to verify the value of musculoskeletal stabilization metrics.

There are generally many things that affect the performance of safety that should be evaluated and defined in the design and pre-construction phase in order to improve safety. Sawacha et al. (1999) explained various variables affecting safety at construction sites. The findings show that variables surrounding the organizational approach are the most significant category of factors influencing safety efficiency in the building industry in the UK.

The findings of a postal survey of manufacturers in Singapore were addressed in another study done (Teo et al., 2005). The results obtained from this study showed that site accidents occur when there are limited company policies, inappropriate practices, inadequate construction workers behaviours, low management commitment performance and insufficient safety awareness and staff training.

In the section below the main elements of improving safety in the construction sector will be discussed (Charehzehi \& Ahankoob, 2012):

- Risk analysis in the planning phase

- Coaching method

- Award policy

- Contractor compliance with the safety regulations

- Supplying safe equipment and resources

- Staff selection

The research aims to establish and suggest the best systems that can be used to reduce accidents in the construction industry by identifying the most common accidents to occur in Northern Iraq.

\section{METHODOLOGY}

This research reviews the literature at the first stage, and then it uses a designed questionnaire to know the most common accidents so that it can suggest good ways to improve safety systems. Then a second questionnaire to get the opinion of experts to know from their experienced point of view, whether these ways are effective or not so that the final suggestions can be beneficial.

To analyse the best strategies, and matters about construction projects safety management, a questionnaire for study methodology was used.

\subsection{Questionnaire}

A structured questionnaire was sent as a set of questions to construction-related experts to collect relevant data, where the questionnaire has included closed and open questions. A vast amount of data (quantitative) gathered 
rapidly from individuals. This can be stated as the questionnaire's most significant benefit.

Table 1. Questions

\begin{tabular}{|c|c|}
\hline Question & Answer \\
\hline \multirow{9}{*}{$\begin{array}{l}\text { In your opinion, which } \\
\text { type of accident is the } \\
\text { most common in the } \\
\text { construction industry? }\end{array}$} & Falls from heights \\
\hline & Slip and falls \\
\hline & Gas leaks, fires, and explosions \\
\hline & Struck-by accidents \\
\hline & Lifting and handling \\
\hline & Electrocutions \\
\hline & Contact by equipment \\
\hline & Trench accidents \\
\hline & Others \\
\hline \multirow{7}{*}{$\begin{array}{l}\text { As a highway's } \\
\text { construction staff } \\
\text { member, which type } \\
\text { of the following } \\
\text { accident is the most } \\
\text { common? }\end{array}$} & Struck-by accidents \\
\hline & Explosion \\
\hline & Trench accidents \\
\hline & Work zone crashes \\
\hline & Contact by equipment \\
\hline & Falls from heights \\
\hline & Slip and falls \\
\hline \multirow{9}{*}{$\begin{array}{l}\text { Which type of the } \\
\text { following accident is } \\
\text { most likely to cause } \\
\text { fatal injuries to } \\
\text { workers? }\end{array}$} & Falls from heights \\
\hline & Slip and falls \\
\hline & Gas leaks, fires, and explosions \\
\hline & Struck-by accidents \\
\hline & Lifting and handling \\
\hline & Electrocutions \\
\hline & Contact by equipment \\
\hline & Trench accidents \\
\hline & Others \\
\hline \multirow{9}{*}{$\begin{array}{l}\text { Which type of the } \\
\text { following accident is } \\
\text { most likely to cause } \\
\text { major injuries to } \\
\text { workers? }\end{array}$} & Falls from heights \\
\hline & Slip and falls \\
\hline & Gas leaks, fires, and explosions \\
\hline & Struck-by accidents \\
\hline & Lifting and handling \\
\hline & Electrocutions \\
\hline & Contact by equipment \\
\hline & Trench accidents \\
\hline & Others \\
\hline \multirow{9}{*}{$\begin{array}{l}\text { Which type of the } \\
\text { following accident is } \\
\text { most likely to cause } \\
\text { lost working time } \\
\text { injuries to workers? }\end{array}$} & Falls from heights \\
\hline & Slip and falls \\
\hline & Gas leaks, fires, and explosions \\
\hline & Struck-by accidents \\
\hline & Lifting and handling \\
\hline & Contact by equipment \\
\hline & Electrocutions \\
\hline & Trench accidents \\
\hline & Others \\
\hline \multicolumn{2}{|l|}{$\begin{array}{l}\text { Have you been } \\
\text { subjected to an } \\
\text { accident and what was } \\
\text { the kind of the } \\
\text { accident? }\end{array}$} \\
\hline $\begin{array}{l}\text { Has a person you } \\
\text { know been subjected } \\
\text { to an accident? And } \\
\text { what was the kind of } \\
\text { the accident? }\end{array}$ & \\
\hline
\end{tabular}

The opinion of professionals over these matters can be developed and studied via the questionnaire. The answers were not immediate; voters were able to reply openly if they had the time and were not afraid to share their opinions.

\subsection{Questionnaire design}

The questionnaire was written in English and Arabic languages, in case the workers did not speak English. Also, the name of the participants was not required for privacy issues.

The questionnaire was as brief as possible, easy and clear to get the maximum answer level possible.

There were 125 samples divided into respondents, and 121 were received, and the respondents were asked to evaluate by (very poor, poor, neutral, good, or very good). Moreover, the Likert system was used, as shown in Table 2.

Table 2. Likert system

\begin{tabular}{|l|c|c|}
\hline Evaluation & Number & Range \\
\hline Very poor & 1 & $1.00-1.80$ \\
\hline Poor & 2 & $1.81-2.60$ \\
\hline Neutral & 3 & $2.61-3.40$ \\
\hline Good & 4 & $3.41-4.20$ \\
\hline Very good & 5 & $4.21-5.00$ \\
\hline
\end{tabular}

\section{RESULTS AND DISCUSSION}

\subsection{General information}

Table 3, introduces the general information of the respondents such as sex, education level, experience and their position. As well as, it introduces the type of the company they work for whether they are private or public.

Table 3. General information

\begin{tabular}{|l|l|r|}
\hline \multirow{2}{*}{ Item } & \multicolumn{2}{|c|}{ Answer } \\
\hline \multirow{5}{*}{ Education } & Male & $86 \%$ \\
\cline { 2 - 3 } & Female & $14 \%$ \\
\cline { 2 - 3 } & Primary & $11 \%$ \\
\cline { 2 - 3 } & Diploma & $9 \%$ \\
\cline { 2 - 3 } & Bachelor & $61 \%$ \\
\cline { 2 - 3 } & Master & $12 \%$ \\
\hline \multirow{5}{*}{ Position } & Ph.D. & $7 \%$ \\
\cline { 2 - 3 } & Designer & $18 \%$ \\
\cline { 2 - 3 } & Site Engineer & $7 \%$ \\
\cline { 2 - 3 } & Consultant & $51 \%$ \\
\cline { 2 - 3 } & Contractor & $3 \%$ \\
\cline { 2 - 3 } & Safety officer & $8 \%$ \\
\cline { 2 - 3 } & Skilled worker & $2 \%$ \\
\cline { 2 - 3 } & Worker & $6 \%$ \\
\hline \multirow{5}{*}{ Experience } & Less than 5 years & $5 \%$ \\
\cline { 2 - 3 } & Between 5 - 10 years & $16 \%$ \\
\cline { 2 - 3 } & Between 10 - 15 years & $20 \%$ \\
\cline { 2 - 3 } & More than 15 years & $17 \%$ \\
\hline \multirow{4}{*}{ Company type } & Public & $26 \%$ \\
\cline { 2 - 3 } & Private & $74 \%$ \\
\hline
\end{tabular}




\subsection{Common accidents}

A questionnaire was carried out were from the analysed the data it was clear that the most common accident in the construction industry was falling from heights with a percentage of $49 \%$ and in the second was slipping and falling with a percentage of $19 \%$ and third was struck-by accidents with a percentage of $16 \%$. As shown in Fig. 1.

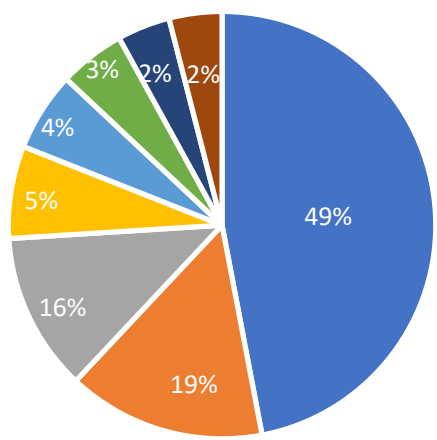

- Falls from heights

- Slip and falls

- Struck-by accidents

= Contact by Equipment

- Electrocutions

- Lifting and handling

- Gas leaks, fires, and explosions. - Trench accidents

Fig. 1. The most common accidents in the construction industry

Trench accident has the minimum ratio with a percentage of $2 \%$. While, in the highway construction sector, Struck-by accidents are the most common accidents with a percentage $60 \%$ and work zone crashes with a percentage of $18 \%$ and trench accidents with a percentage of $11 \%$. As shown in Fig. 2.

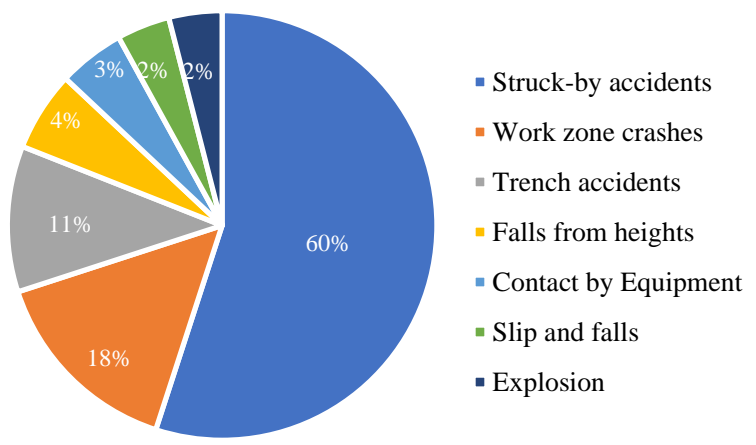

Fig. 2. The most common accidents in highway construction

Explosion accidents have the minimum ratio with a percentage of $2 \%$. Also, the participants were asked to rank the which type of the accidents is most likely to cause fatal injuries to workers, according to the data falls from heights with a percentage of $51 \%$ came at the first stage, followed by struck-by accidents $16 \%$ and contact by equipment $13 \%$. As shown in Fig. 3.

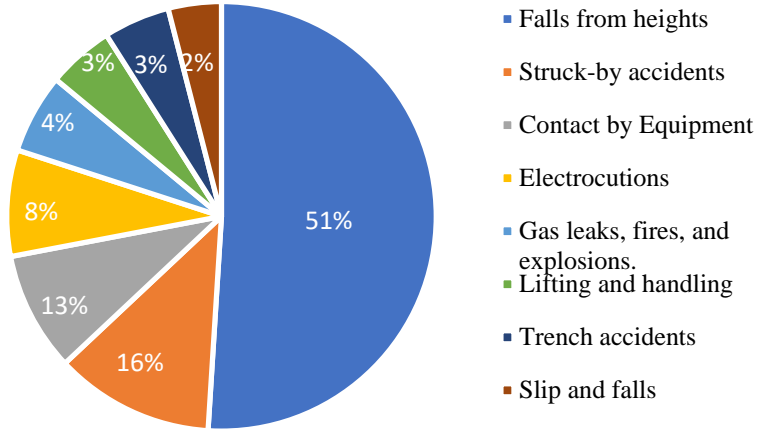

Fig. 3. Most likely accidents to cause fatal injuries to workers

Slip and falling accidents have the minimum ratio with a percentage of $2 \%$. Also, the accidents that are most likely to cause major injuries to workers were falls from heights $31 \%$, Slip and falls $28 \%$, and Struck-by accidents $13 \%$. As shown in Fig. 4.

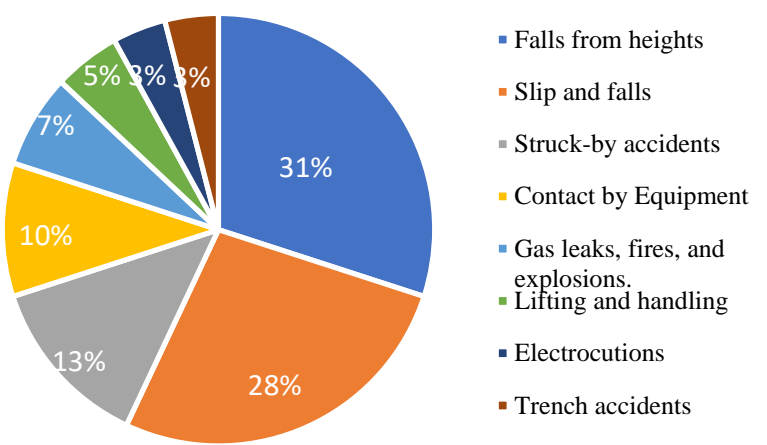

Fig. 4. Most likely accidents to cause major injuries to the worker

Trench accident has the minimum ratio with a percentage of 3\%. The accident most likely to cause loss of working time to the workers is lifting and handling $36 \%$, with slip and falls $25 \%$, and falls from heights $14 \%$. As shown in Fig. 5.

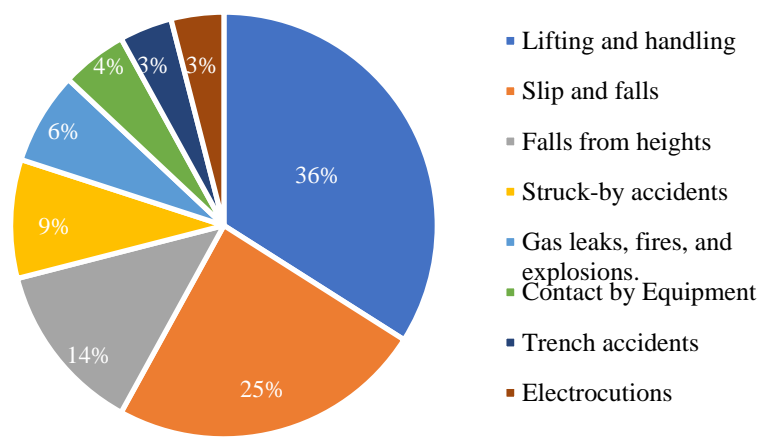

Fig. 5. Most likely accidents to cause lost working time injuries to workers

Electrocution accidents have the minimum ratio with a percentage of $3 \%$. Besides, the respondents were asked to discuss accidents they have faced or people they know. 
According to their answers, falling from heights was the first and foremost common accident type in construction. While in highway construction projects, struck-by accidents were the top accident type. This may be illustrated by the poor state of scaffolding and the poor state of supervising the equipment in progress on highway projects.

\subsection{Best ways to reduce accidents}

A questionnaire was carried out to gather information from site users to know which strategies are the right way to reduce accidents on construction sites. There were 19 questions asked, and the respondents were asked to evaluate how good or bad they in minimizing the accidents numbers. As shown in Table 3 and Fig. 6. From the results of the questionnaire, several recommendations were concluded to be illustrated in the next section.

Table 3. Assessment of ways for reducing accidents

\begin{tabular}{|l|l|}
\hline $\mathbf{N o}$ & Question \\
\hline $\mathbf{1}$ & $\begin{array}{l}\text { Do you get any benefit from the safety man in the } \\
\text { project? }\end{array}$ \\
\hline $\mathbf{2}$ & Do you get any benefit from the safety meetings? \\
\hline $\mathbf{3}$ & $\begin{array}{l}\text { The role of a designer in minimizing accidents in } \\
\text { construction projects? }\end{array}$ \\
\hline $\mathbf{4}$ & $\begin{array}{l}\text { The role of a site engineer in minimizing accidents in } \\
\text { construction projects? }\end{array}$ \\
\hline $\mathbf{5}$ & $\begin{array}{l}\text { The role of a contractor in minimizing accidents in } \\
\text { construction projects? }\end{array}$ \\
\hline $\mathbf{6}$ & $\begin{array}{l}\text { The role of a manager in minimizing accidents in } \\
\text { construction projects? }\end{array}$ \\
\hline $\mathbf{7}$ & $\begin{array}{l}\text { Does the training of the staff help in minimizing } \\
\text { accidents? }\end{array}$ \\
\hline $\mathbf{8}$ & $\begin{array}{l}\text { Can the authorities, workers union laws and } \\
\text { monitoring, reduce accidents? }\end{array}$ \\
\hline $\mathbf{9}$ & $\begin{array}{l}\text { The role of the worksite first aid in minimizing the } \\
\text { deaths in construction projects? }\end{array}$ \\
\hline $\mathbf{1 0}$ & Can accidents recording process reduce accidents? \\
\hline $\mathbf{1 1}$ & The role of fund in minimizing accidents? \\
\hline $\mathbf{1 2}$ & The role of signs and signals in minimizing accidents? \\
\hline $\mathbf{1 3}$ & Can guidelines of a company reduce accidents? \\
\hline $\mathbf{1 4}$ & $\begin{array}{l}\text { Can the psychological state of the worker increase } \\
\text { accidents? }\end{array}$ \\
\hline $\mathbf{1 5}$ & Can personal protective elements increase accidents? \\
\hline $\mathbf{1 6}$ & Can limiting the speed reduce accidents? \\
\hline $\mathbf{1 7}$ & $\begin{array}{l}\text { Can providing a sound lighting system reduce } \\
\text { accidents? }\end{array}$ \\
\hline $\mathbf{1 8}$ & $\begin{array}{l}\text { Can wearing Hi-Vis clothing reduce accidents on } \\
\text { highways projects? }\end{array}$ \\
\hline $\mathbf{1 9}$ & $\begin{array}{l}\text { Can replacing the flagmen with electronic systems } \\
\text { reduce deaths on highway work zones? }\end{array}$ \\
\hline
\end{tabular}

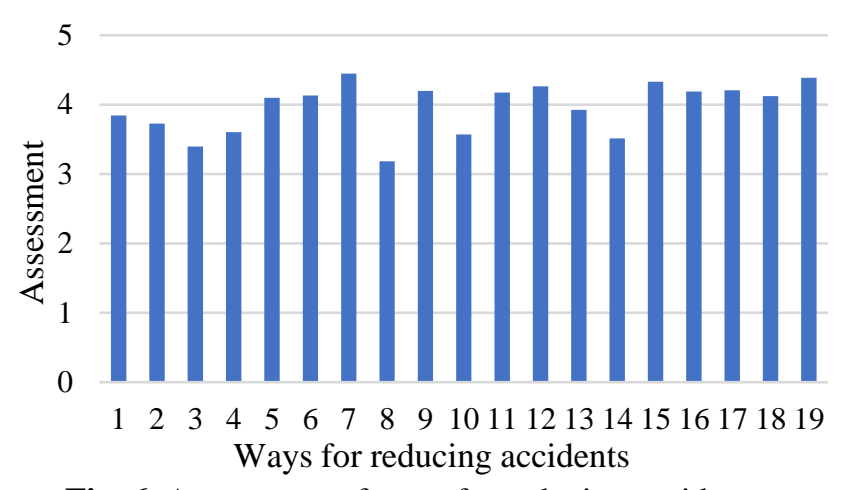

Fig. 6. Assessment of ways for reducing accidents

\section{BEST WAYS TO REDUCE ACCIDENTS}

The most effective ways to reduce accidents and the following recommendations were gotten:

\subsection{General recommendations}

- The authorities should be concerned with labour and workers affairs such as the Department of Labour and Social Security. Also, the workers' union must place the conditions and laws that guarantee the life of the worker and his duties. Furthermore, providing safety and public safety conditions to enrich his work values and provide oversight bodies to monitor and emphasize contractors and employers, on their need to provide professional safety requirements. And personal protection equipment for workers in the workplace.

- A clause must be included in the contract requiring the contractor to provide the necessary measures for occupational safety in the workplace.

- Training programs must be provided for workers in the workplace, especially the youth who often lack experience, to inform them about the work that they will perform on the site and the risks that may encounter in case they neglect the requirements of occupational safety. They should also be sensitized to occupational safety guidelines and instructions and alerted about the penalties they may face if they break those instructions.

- Emphasis on providing first-aid facilities such as a firstaid box at the workplace. Also, appointing and training a person in how to assist an injured colleague.

- All governmental and non-governmental agencies must organize records to record and preserve information related to accidents and work injuries. As well as, information on the injured worker, plus organize a form that is applied in practice (accident report) in which they provide information about the injured person, their age, cause of injury and the location, in order to study these incidents and reduce them in the future. 
- Emphasizing the provision of a section on safety in contracting companies, activating their oversight role on worksites, setting plans that contribute to avoiding and reducing risk, plus providing a safe environment for workers to increase production at work.

- Providing a sufficient fund and budget for safety requirements.

- Providing protection with firefighting systems, safety cameras, signs and signals.

- Provide guidelines in the companies about how to use equipment safely, to ensures the safety of the user.

- Not allowing a worker to suffers from emotional pressures.

- Not authorizing any workers to work without personal protective equipment.

- Completing daily meetings to inform and teach the workers about safety issues.

- Providing all new workers information about the place of work. Data to ensure the reduction of any risks in the workplace.

- Onsite signs should be provided about safety and speed limits.

- When excavating or something similar, there should be a safety tape place around the workplace.

- Not allowing staff to work without PPE, such as wearing masks when dealing with chemical materials and wearing gloves when dealing with electricity.

\subsection{Falling from heights recommendations}

- Do not work on scaffold if it is not essential to your work

- If it is an essential part of the work, the following points should be taken into consideration

- The scaffold should be strong enough to carry the applied loads from workers, materials and machinery.

- The scaffold support is strong enough.

- The scaffold is stable and unable to over-turn.

- Putting guard rails on the scaffolds.

- In the case of working on heights more than one-meter, a safety belt should be worn and attached to the scaffold.

- Do not overload ladders.

- Only work at a height where it is reasonably necessary

- Minimize the elevation and effects of a fall by using the correct type of device where the danger can not be removed.

\subsection{Highways recommendations}

- A worker should wear Hi-Vis clothing.

- Signs should be placed to inform drivers about the work zone.

- The signs should be placed a distance from the work zone to give the drivers a distance to reduce speed.
- There should be speed limit signs that introduce a gradual reduction of speed, not a sudden reduction.

- Alternative techniques like using electronic road control systems should be used as much as possible to reducing the number of flagmen.

- When a truck or equipment is manoeuvring there should be a supervisor present.

- When working during the night, a good lighting-system should be in place.

- Lighting-systems on equipment should be checked.

- All equipment should be checked before being used.

- When more than one piece of equipment is working at the same time, there should be a supervisor ensuring safety procedures are in place.

\section{CONCLUSIONS}

This study has been conducted to find the most common accidents types within the construction industry in Northern Iraq and also to find effective ways to reduce accidents. The study showed that the most common accidents in the building sector are falling from heights, while in highway construction struck-by accidents were the most common accident type. Also, a survey was done to get the opinion from experts to find the best ways to reduce accidents. There were some effective ways found, as mentioned in the last section.

\section{REFERENCES}

[1] Alsumaria (2019). Death of 38 workers in Northern Iraq.

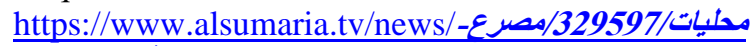
38

[2] Australia, S. W. (2013). Work-related injuries and fatalities involving a fall from height. Safe Work Australia: Canberra, Australia.

[3] BLS "Bureau of Labour Statistics". (2015). Fatal Occupational Injuries by Industry and Event or Exposure. http://www.bls.gov/news.release/cfoi.t01.htm

[4] Charehzehi, A., \& Ahankoob, A. (2012). Enhancement of safety performance at construction site. International Journal of Advances in Engineering \& Technology, 5(1), 303.

[5] Derr, J., Forst, L., Chen, H. Y., \& Conroy, L. (2001). Fatal falls in the US construction industry, 1990 to 1999. Journal of occupational and environmental medicine, 43(10), 853-860. https://doi.org/10.1097/00043764-200110000-00004

[6] Fung, I. W., Tam, C. M., Tung, K. C., \& Man, A. S. (2005). Safety cultural divergences among management, supervisory and worker groups in Hong Kong construction industry. International journal of 
project management, 23(7), 504-512. https://doi.org/10.1016/j.ijproman.2005.03.009

[7] Griffith, A., \& Howarth, T. (2001). Construction health and safety management. $1^{\text {st }}$ Ed. Pearson Education.

[8] Hanapi, N. M., Kamal, M. M. M., Ismail, M. I., \& Abdullah, I. A. P. (2013). Identifying root causes and mitigation measures of construction fall accidents. Gading Journal for the Social Sciences, 17(01), 65-79.

[9] HSE "Health and Safety Executive". (2019). Construction statistics in Great Britain.

[10] Howarth, T., \& Watson, D. P. (2009). Construction safety management. $1^{\text {st }}$ Ed. Wiley-Blackwell.

[11] HSE "Health and Safety Executive". (2015). Health and Safety in Construction Sector in Great Britain 2014/15.

[12] Hu, K., Rahmandad, H., Smith-Jackson, T., \& Winchester, W. (2011). Factors influencing the risk of falls in the construction industry: a review of the evidence. Construction Management and Economics, 29(4), 397-416. https://doi.org/10.1080/01446193.2011.558104

[13] Huang, X., \& Hinze, J. (2003). Analysis of construction worker fall accidents. Journal of construction engineering and management, 129(3), 262-271.

https://doi.org/10.1061/(ASCE)07339364(2003)129:3(262)

[14] Hughes, P., \& Ferrett, E. (2015). Introduction to Health and Safety at Work: For the NEBOSH National General Certificate in Occupational Health and Safety. Routledge. https://doi.org/10.4324/9781315857893

[15] Irimie, S., Munteanu, R., Ghicajanu, M., \& Marica, L. (2015). Aspects of the Safety and Health at the Workplace. Procedia economics and finance, 23(3), 152-160. https://doi.org/10.1016/S2212-5671(15)00390-1

[16] Janicak, C. A. (1998). Fall-related deaths in the construction industry. Journal of Safety Research, 29(1), 35-42. https://doi.org/10.1016/S0022-4375(97)00027-3

[17] Jebelli, H., Ahn, C. R., \& Stentz, T. L. (2014). The validation of gait-stability metrics to assess construction workers' fall risk. In Computing in Civil and Building Engineering, 2014, 997-1004. https://doi.org/10.1061/9780784413616.124

[18] OSHA "Occupational Safety and Health Administration“. United States Department of labour (2020). Data \& Statistics.

[19] Persia, L., Usami, D. S., De Simone, F., De La Beaumelle, V. F., Yannis, G., Laiou, A., \& Salathè, M. (2016). Management of road infrastructure safety. Transportation research procedia, 14, 3436-3445. https://doi.org/10.1016/j.trpro.2016.05.303

[20] Pigman, J. G., \& Agent, K. R. (1988). Analysis of accidents in construction and maintenance work zones.
[21] Reese, C. D. (2018). Occupational health and safety management: a practical approach. CRC press. https://doi.org/10.1201/9781351228848

[22] Rubio-Romero, J. C., Gámez, M. C. R., \& CarrilloCastrillo, J. A. (2013). Analysis of the safety conditions of scaffolding on construction sites. Safety science, 55, 160-164. https://doi.org/10.1016/j.ssci.2013.01.006

[23] Sawacha, E., Naoum, S., \& Fong, D. (1999). Factors affecting safety performance on construction sites. International journal of project management, 17(5), 309-315. https://doi.org/10.1016/S0263-7863(98)00042-8

[24] Schaufelberger, J., \& Lin, K. Y. (2013). Construction Project Safety (Vol. 93). John Wiley \& Sons.

[25] Teo, E. A. L., Ling, F. Y. Y., \& Chong, A. F. W. (2005). Framework for project managers to manage construction safety. International Journal of project management, 23(4), 329-341. https://doi.org/10.1016/j.ijproman.2004.09.001

[26] Zhao, T., Kazemi, S. E., Liu, W., \& Zhang, M. (2018). The Last Mile: Safety Management Implementation in Construction Sites. Advances in Civil Engineering, 2018, 1-15. https://doi.org/10.1155/2018/4901707 